\title{
Development of Secondary School Students Critical Thinking as a Strategic Priority of Modern Education: Goals, Objectives and Outcomes
}

\author{
Andrei V. Samoilov* \\ Moscow School of Social and Economic Sciences \\ 2 building, 82 Vernadskogo, Moscow, 119571, Russia
}

Received 21.09.2014, received in revised form 20.10.2014, accepted 14.11.2014

\begin{abstract}
The National Federal Education Standards define critical thinking skills as one of the main features of the "school graduate's portrait". In this regard, critical thinking skills, the efficiency of which on each level can be evaluated with specific criteria, should be properly defined in national standards and programs. This article provides an analysis of foreign experience (Singapore, Finland, Hong Kong, and Australia) in critical thinking development as a possible way of implementing critical thinking ideology in Russian school education. The author makes an attempt to define a set of requirements for determination of the main criteria of the critical thinking skills development, and suggest some methods for critical thinking assessment to be used by the authors of the National Federal Education Standards.
\end{abstract}

Keywords: critical thinking, assessment, national standards and programs, main criteria of the critical thinking skills development.

Research area: psychology.

\section{Introduction}

Looking at the current state of Russian society, it is evident that there is no need to emphasize the importance of reforming all state institutions. A radical reform in education should be the most important issue among these changes. The new National Federal Education Standards setting the objective for the total transformation of Russian educational system coming into play have been approved. In this regard, the development of critical thinking in all groups of students is the cornerstone in the emerging reform strategy of modern education, since the transition to the critical thinking ideology is one of the main ways of solving the problem of key competence development and one of the main characteristics of the educational reform in Russia. Secondary school students play a special role in the development of this ideology, as the National Federal Education Standards define critical thinking as one of the main features of the "school graduate's portrait" (Russian Newspaper, 2011). For this reason, there is an obvious need for the development of such strategy of critical

(C) Siberian Federal University. All rights reserved

* Corresponding author E-mail address: samoylovslab@gmail.com 
thinking development, which would combine the best foreign experience, at the same time relying on those social, economic and ideological conditions Russian education system exists in. The transition to critical thinking ideology is indeed an approach to solving the problem of development of the key competences that "are needed for individuals to live a successful and responsible life and for the society to face the challenges of the present and the future" (OECD. Definition and Selection of Competencies).

\section{Theoretical framework}

This article provides analysis of foreign experience in critical thinking development as a possible way of implementing the critical thinking ideology in Russian school education. The most important educational outcomes are described in the international survey Programme for International Student Assessment (PISA) designed to test the level of school students key competences and detect the deficiency in academic skills of Russian school students (for example, working with information and analysis). Such skills are assessed in Reading Literacy domain of PISA and include the following dimensions (OECD. PISA 2012):

1. Retrieve texts and access them;

2. Interpret and integrate texts;

3. Reflect and evaluate texts.

Student performance in Reading Literacy domain is currently divided into seven levels (while in the international surveys PISA 2000, PISA 2003, PISA 2006 reading literacy results were presented in five levels). Thus, the highest reading literacy level means that the reader is able to "locate and possibly sequence or combine multiple pieces of deeply embedded information, some of which may be outside the main body of the text. Infer which information in the text is relevant to the task; deal with highly plausible and/or extensive competing information; either construe the meaning of nuanced language or demonstrate a full and detailed understanding of a text; critically evaluate or hypothesise, drawing on specialised knowledge; deal with concepts that are contrary to expectations and draw on a deep understanding of long or complex texts" (OECD. Reading for Change).

As we can see, PISA reading literacy skills have certain features in common with the basic concepts and components of critical thinking that is "at the core of most intellectual activity that involves students in learning to recognise or develop and use information to solve problems. Examples of thinking skills are interpreting, analysing, evaluating, explaining, sequencing, reasoning, comparing, questioning, inferring, hypothesising, appraising, testing and generalizing" (Australian Curriculum. Critical and creative thinking).

Reading literacy statistics provides the basis for country rating, to show whose students demonstrate the best results. Based on this statistics we can assume that in the education systems that reached the highest score much work on the development of school students' critical thinking is in progress. Therefore, we have selected the top countries in PISA literacy for the analysis of their experience in developing critical thinking skills. It seems logical that according to their results in the Reading Literacy domain of PISA 2000, 2003, 2006, 2009 and 2012 these countries are in the top ten. Here are the score achieved by these countries (Table).

The 2000 study showed that Russian students were ranked $27-29^{\text {th }}$ among 32 countries in Reading Literacy domain. The average result of Russia is 462 points (on a scale from 0 to 1,000 ). The 2003 study showed that Russian students are ranked $32-34^{\text {th }}$ among 40 countries in Reading Literacy domain. The average result of Russia is 442 points. A 2006 study found that Russian 
Table

\begin{tabular}{|l|l|l|l|l|l|}
\hline \multicolumn{1}{|c|}{ PISA 2000 } & \multicolumn{1}{|c|}{ PISA 2003 } & \multicolumn{1}{|c|}{ PISA 2006 } & \multicolumn{1}{c|}{ PISA 2009 } & \multicolumn{1}{c|}{ PISA 2012 } \\
\hline 1 & Finland 546 & Finland 543 & Korea 556 & Shanghai 556 & Shanghai 570 \\
\hline 2 & Canada 534 & Korea 534 & Finland 547 & Korea 539 & Hong Kong 545 \\
\hline 3 & New Zealand 529 & Canada 528 & Hong Kong 536 & Finland 536 & Singapore 542 \\
\hline 4 & Australia 528 & $\begin{array}{l}\text { Australia 525 } \\
\text { Liechtenstein 525 }\end{array}$ & Canada 527 & Hong Kong 533 & Japan 538 \\
\hline 5 & Ireland 527 & New Zealand 522 & New Zealand 521 & Singapore 526 & Korea 536 \\
\hline 6 & $\begin{array}{l}\text { Korea 525 } \\
\text { Hong Kong 525 }\end{array}$ & Ireland 515 & Ireland 517 & Canada 524 & Finland 524 \\
\hline 7 & $\begin{array}{l}\text { UK 523 } \\
8\end{array}$ & Sweden 514 & Australia 513 & New Zealand 521 & $\begin{array}{l}\text { Ireland 523 } \\
\text { Taiwan 523 } \\
\text { Canada 523 }\end{array}$ \\
\hline 9 & $\begin{array}{l}\text { Sweden 516 } \\
\text { Japan 522 }\end{array}$ & Hotherlands 513 Kong 510 & Liechtenstein 510 & Japan 520 & Poland 518 \\
\hline 10 & $\begin{array}{l}\text { Austria 507, } \\
\text { Icelgium 507, } 507\end{array}$ & Belgium 507 & $\begin{array}{l}\text { Sweden 507, } \\
\text { Netherlands 507 }\end{array}$ & Netherlands 508 & $\begin{array}{l}\text { New Zealand 512 } \\
\text { Australia 512 }\end{array}$ \\
\hline
\end{tabular}

students were ranked $37-40^{\text {th }}$ among 57 countries in Reading Literacy domain. The average result of Russia is 440 points. The 2009 study found that Russian students were ranked $41-43^{\text {rd }}$ among 65 countries in Reading Literacy domain. The average result of Russia had grown to reach 459 points. And the 2012 study found that Russian students were ranked $38-42^{\text {nd }}$ among 65 countries in Reading Literacy domain. The average result of Russia was 475 points.

Any of the top countries are of interest for the analysis of their highest-performing education systems for the purpose of studying their experience in developing critical thinking skills. However, only some of them will be analysed to determine the possible models.

\section{Problem statement}

What is the set of requirements that enable critical thinking development and what are the main criteria to indicate the development? The answers to these questions may formulate recommendations for the authors of the National
Federal Education Standards. In this regard, it appears advisable to analyse the highestperforming education systems for the purpose of studying their experience in developing critical thinking skills. Their experience can be interesting not only as an object of comparison, but also as a possible model of critical thinking development in Russian education system.

\section{Methods}

1. Carry out a comparative analysis of different versions of educational standards and programs of these countries to determine their requirements and the methods of critical thinking development.

2. Determine how countries describe the level of the students' critical thinking in their national standards and programs.

3. Define how these countries assess the levels of critical thinking development.

4. Analyse the National Federal Education Standards and programs in Russia to determine the presence of any requirements for critical 
thinking development and essential criteria of its development.

5. Formulate recommendations for the authors of the National Federal Education Standards.

\section{Discussion}

The analysis of education systems of Finland, Hong Kong and Australia shows that all these countries carry out a deliberate policy of critical thinking development. It should be noted that in their education documents these countries define critical thinking skills differently: in some countries the skills are included in the list of key interdisciplinary skills or competences, in others such skills constitute a part of any set of interdisciplinary skills.

The analysis of the critical thinking development in the educational system of Finland shows that according to the Government Decree on the General National Objectives of General Upper Secondary Education and the Distribution of Lesson Hours (2002) critical thinking is one of the main objectives of secondary education. National Core Curriculum for Basic Education 2004 refers to critical thinking among the required skills that reveal the concepts of such interdisciplinary skills as "media and communication skills" and "active citizenship and entrepreneurship". The report of the Ministry of Education and Culture of Finland in 2012 "Basic education for the future: national objectives and distribution of hours" defines critical thinking as a required skill for middle school students and describes it as a mandatory requirement in the objectives set within primary school standards in such disciplines as Biology, Geography, Health, Visual arts, and Ethics. National high school curriculum defines critical thinking skills as a part of such interdisciplinary skills as active citizenship and entrepreneurship, media and communicative competence.
Learning Objectives and Core Contents Of Education for Upper Secondary Schools defines critical thinking within such subject areas as Native Language and Literature, Biology, Geography, Chemistry, Religion, Ethics, Philosophy, History, Social studies, Psychology, Music, Visual arts and Health education. It should be noted that National Core Curriculum for Upper Secondary Schools and National Core Curriculum for Basic Education do not describe critical thinking skills through the expected outcomes according to possible levels of critical thinking development. Critical thinking skills are assessed by teachers within the disciplinary assessment which is also described in National Core Curriculum for Upper Secondary Schools. Finnish Matriculation Examination in the mother tongue exam includes such elements of critical thinking as the ability to find arguments and to interpret the text, to critically evaluate information, to pick up arguments, etc. in its assessment criteria. (Finnish Matriculation Examination, 2012). The mother tongue exam statistics for the essay and for the textual skills subtest are presented separately in order to measure the students' critical and cultural literacy and linguistic expression skills (Finnish Matriculation Examination, 2007).

The analysis of Hong Kong educational system shows that the problem of critical skills development has existed in Hong Kong education policy since the 1980's (Edward Vickers and Flora Kan, 2003), and since 1997 the development of ICT literacy, critical and creative thinking have been widely discussed as the conditions necessary for the creation of knowledge economy. The Education Commission of Hong Kong included critical thinking skills development into the education reform project in 2000 and specified the basic learning objectives for students in the $21^{\text {st }}$ century (Education Commission, 2000), and in 
2001 Curriculum Development Council included critical thinking in the nine generic skills list (Education Commission, 2003). General Studies for Primary Schools Curriculum Guide (2002) in the Short-term Expectations (from 2002 to 2006) noted the need for the development of such subject knowledge generic skills of students as critical thinking, creative thinking and communication skills in the curriculum framework design, setting the learning targets and objectives. In General Studies for Primary Schools Curriculum Guide (2011) we can also notice the same nine generic skills. This Curriculum Guide determines that "schools can create curriculum space by spending about $80 \%$ of the total learning time on the core elements recommended in this curriculum guide and flexibly arrange the remaining 20\%" for the extension part of the curriculum to develop critical thinking skills. The program intends to consider the level of critical thinking development while providing formative and summative assessment. Academic Structure for Senior Secondary Education and Higher Education (2005) and Student Programme for Achievement of the Vision of the New Academic Structure, Whole-person Development and Life-Long Learning for the years 2007-2012 name critical thinking skills among the main objectives of the education reform. But only in English course for senior high school we can find a unit devoted to these skills divided into two levels (the first three years (junior high school) and the last three years (senior high school) (Education Bureau, 2007). These two levels include indicators of the expected outcomes in the area of critical thinking skills in respect with the learning targets and objectives. The latest versions of other subjects' description only define common critical thinking components, but do not specify how such skills can be developed within an individual disciplinary course. However, they recommend considering the critical thinking skills development level when carrying out formative assessment. There are no direct requirements for the critical thinking skills assessment in the exam papers recommended for elementary school (Education Bureau, 2010), but the exam for Hong Kong Diploma of Secondary Education (HKDSE) does include some critical thinking skills assessment (Hong Kong Examinations and Assessment Authority, 2012a, 2013a, 2013b). However, Hong Kong statistics does not show any analysis of the critical thinking development level (Education Commission, 2006; Hong Kong Examinations and Assessment Authority, 2012b).

The analysis of Australian educational system concerning critical thinking development shows that critical thinking skills development is considered to be one of the fundamental requirements for students in Australia's Common and Agreed Goals for Schooling in the Twenty First Century (The "Hobart Declaration") (1989, 1998), Adelaide Declaration on National Goals for Schooling in the Twenty-First Century (1999), Melbourne Declaration on Educational Goals for Young Australians (2008), the Government program "Global Perspectives: a framework for global education in Australian schools" (2002), Australian Qualification Framework. Australian Curriculum, Assessment and Reporting Authority defines critical thinking as one of the seven general capabilities that are addressed explicitly in the content of the learning areas (Singapore Examinations and Assessment Board). The critical thinking learning continuum is organized into four interrelated elements (inquiring (identifying, exploring and organizing information and ideas); generating ideas, possibilities and actions; reflecting on thinking and processes; analysing, synthesizing and evaluating reasoning and procedures) and every element is described in 6 levels. The analysis of 
History curriculum published in 2013 shows that the requirements for critical thinking development are organized into four elements from the first year to year 10 according to 6 levels (Australian Curriculum: History). The assessment of critical thinking skills can be done through portfolios, obligatory tasks for students from the first year to year 10 in all learning areas and have 3 levels: below satisfactory, satisfactory or above satisfactory level according to the achievement standards (Work Sample Portfolio). Moreover, National Assessment Program includes indicators for critical thinking skills evaluation (National Assessment Program - Civics and Citizenship. Assessment Framework) into the specification for Civics and Citizenship assessment test (for $6^{\text {th }}$ and $10^{\text {th }}$ year students). The exam statistics show the educational outcomes according to the five levels determined for evaluation of critical thinking skills development (National Assessment Program. Civics and Citizenship. Years 6 and 10. Report 2010).

The analysis of Russian educational system concerning critical thinking development shows that the generic academic skills are not described in the standards and curriculum or in Russian Federal Law "On education” as of 1992 and 2012. National Federal Education Standards (2004) determined the requirements for the development of general academic skills, but did not specify them. Only in the Concept of modernization of Russian education for the period up to 2010 one can find the requirements for universal learning skills development. Since 2004, in some disciplinary standards critical thinking has been defined as a mandatory skill for development (Social studies, Mathematics, Science, History, Economics), and in some subject areas only some elements of critical thinking (e.g., Russian Language) have been described (Russian Education Portal, 2004). But there are no descriptions of requirements or levels of critical thinking skills development.
There are no recommendations and methodology for critical thinking skills evaluation. The Government draft of the Russian Federation state program "Development of Education" for the years 2013-2020 defines the leading role of universal education skills for the key competencies development. The new National Federal Primary Education Standard (2009) and the new National Federal Basic Education Standard determine four elements of the universal educational skills: personal, regulatory, cognitive and communicative. And the new National Federal Secondary Education Standard determines three universal educational actions: regulatory, cognitive and communicative. All these four blocks are used for the development of interdisciplinary skills, while critical thinking skills are a part of the universal education skills. In the new National Federal Primary Education Standard critical thinking skills are developed with the help of texts and with the ICT-competence development. The new National Federal Basic Education Standard contains requirements for continuation of the work on the textual skills for critical thinking development through such subjects as Social studies, Geography and Chemistry (Savinov, 2011). The evaluation system includes assessment of interdisciplinary skills (in particular, the critical thinking skills are included into the evaluation system in project activity). However, the standards do not describe the levels of critical thinking development in those subjects where critical thinking is one of the goals. National Federal Secondary Education Standard defines critical thinking as one of the main features of the "school graduate's portrait" that can be developed throughout such subject area as Social Science. As for the requirements for the critical thinking skills assessment, it can be done with the help of individual projects. The specifications of the Unified State Exam in Social Science and State final attestation in 
Social Science include some elements of critical thinking skills in the evaluation system. But due to their characteristics, such exams cannot show objective statistical data on the level of the critical thinking skills development.

As we can see, all these countries do not use any particular test to obtain information about the level of the critical thinking skills development. The assessment of such is included in the examination papers on different subject areas, provided through the formative assessment. In our opinion, the critical thinking in the educational system of Singapore can be of special interest. Thus, all high school students (Singaporean A-level curriculum) except for those who choose the subject Knowledge and Inquiry (Higher level 2), must study a compulsory General Paper subject (Higher level 1). The Knowledge and Inquiry subject consists of three blocks: block 1 "Understanding the Nature and Construction of Knowledge", block 2 "Critical Thinking" and block 3 "Communication" (Singapore Examinations and Assessment Board. Knowledge and Inquiry Higher 2, 2013). The second block of Knowledge and Inquiry is completely devoted to the development of critical thinking skills and is closely related to the skills of the first and the third blocks. The educational system of Singapore conducts an exam on this subject, evaluated with Singapore-Cambridge General Certificate of Education Advanced Level. Students are assessed according to three tasks: 1. essay 2. critical thinking and 3. independent study. The essay consists of two sections and six questions; students choose one question from each section. These sections cover general theoretical aspects of the subject and their specific application. The second part of the exam also consists of two sections. In the first section a veiled question related to the theme of nature and knowledge is offered, and in the second section three questions on different topics of Knowledge and Inquiry are offered for argument evaluation. The third block of the examination paper is an independent study carried out within six months during the course, the results of which must be presented at the exam. Analysing the second block of examination papers we can detect such requirements and expected outcomes as the ability to critically analyse arguments, information, opinions presented in the texts; the ability to identify and assess assumptions and points of view, to verify claims and the ability to provide and support the arguments. It should be noted that each part of the examination is evaluated according to three criteria: understanding of the nature and device knowledge, critical thinking and ability to communicate. As for the course and General Paper exam (Higher level 1), it consists of three blocks, the first two blocks assess the ability to analyse and evaluate issues, the ability to formulate convincing arguments to demonstrate the skills of critical and creative thinking when answering the questions, the ability to synthesize, evaluate the information, and etc. (Singapore Examinations and Assessment Board. General Paper, 2013).

\section{Conclusion / Results}

The issue of the critical thinking skills development in the educational system of Russia came into play on the legislative level with the introduction of National Federal Education Standardonlyin 2010. Russia determinesasetof the interdisciplinary skills including critical thinking skills described as the expected educational outcomes of some subjects. However, as any other educational outcomes, critical thinking skills should involve the main criteria to indicate its development. An example of this can be observed in Australian education system. First, to carry out the assessment, the requirements or criteria must be specified for a formative or a summative one. Secondly, in each subject area the requirements 
for critical thinking development levels must be described. It is needed for teachers to know, what is necessary to teach and at what grade. The lack of requirements to the critical thinking development levels is the first significant problem that is logically connected with the next problem, which is the system for assessment. The analysis shows that foreign countries solve this problem in different ways .Finland with its high level of moral education and state-supported belief in the high educational achievements of all students provides evaluation of critical thinking skills based on the formative assessment. However, Finnish final examination system also includes assessment of the critical thinking development level. As well as Finland, Hong Kong provides formative assessment of the critical thinking development level and conducts the final assessment at senior high school through including some criteria of critical thinking skills in the examination papers. Singapore, which can be also characterized by a high level of ideological education, solves this problem by using a separate binding exam and the formative assessment system. Australia creates a portfolio system (formative assessments for each grade and each subject) and a national exam which also checks critical thinking skills. In Russia only state exams assess several elements of critical thinking. It should also be noted that the specifications for such exams only refer to the previous versions of standards that did not include any goals to develop some universal education skills. Besides, being high-stakes tests, these exams have a high level of risk. That is why they cannot provide correct statistical data on the level of critical thinking skills development. However, National Federal Primary, Basic and Secondary Education Standards involve critical thinking skills as one of the assessment objects of the formative assessment. Although since 2010 Russia has been making a move to conduct the critical thinking development education policy, it should be noted that these attempts can only refer to those students moving on to the new National Federal Education Standards. There is an obvious need to develop some compensatory steps for critical thinking development as a part of the generic learning skills for those students who continue their education under the previous version of the standards.

\section{References}

1. Australia's Common and Agreed Goals for Schooling in the Twenty First Century (The “Hobart Declaration”), Available at: http://www.mceecdya.edu.au/verve/_resources/natgoals_file.pdf (accessed 10 February 2014).

2. AustralianCurriculum.Criticalandcreativethinking,Availableat:http://www.australiancurriculum. edu.au/GeneralCapabilities/Pdf/Critical-and-creative-thinking (accessed 10 February 2014).

3. Australian Curriculum: History, Available at: http://www.australiancurriculum.edu.au/ History/Rationale (accessed 10 February 2014).

4. Australian Qualification Framework, Available at: http://www.aqf.edu.au/Portals/0/ Documents/2013\%20docs/AQF\%202nd\%20Edition\%20January\%202013.pdf (accessed 10 February 2014).

5. Education Bureau. English Language Curriculum and Assessment Guide (Secondary 4 -6). English Language Education. Key Learning Area. Jointly prepared by the Curriculum Development Council and the Hong Kong Examinations and Assessment Authority. Recommended for use in schools by the Education and Manpower Bureau. HKSARG. (2007), Available at: http://334.edb.hkedcity.net/ doc/eng/eng_lang_final.pdf (accessed 10 February 2014). 
6. Education Bureau. English Language. KS3 (S.1-S.3) Basic Competencies. Assessment for Learning Resource Bank. (2010) Available at: http://wlts.edb.hkedcity.net/en/english/ks3/reading/ 16_r_2_s3bc.html (accessed 10 February 2014).

7. Education Bureau. General Studies for Primary Schools Curriculum Guide (2002), Available at: https://cd.edb.gov.hk/kla_guide/GS_HTML/english/frame.html (accessed 10 February 2014).

8. Education Bureau. General Studies for Primary Schools Curriculum Guide (Primary 1 Primary 6). Prepared by The Curriculum Development Council Recommended for use in schools by The Education Bureau. HKSARG. (2011), Available at: http://www.edb.gov.hk/attachment/en/ curriculum-development/cross-kla-studies/gs-primary/gs_p_guide-eng_300dpi-final\%20version.pdf (accessed 10 February 2014).

9. Education Commission. Education Statistics. (2006), Available at: http://www.e-c.edu.hk/ eng/reform/Edu\%20Stat\%20(Eng)\%202006.pdf (accessed 10 February 2014).

10. Education Commission. Reform Proposals for the Education System in Hong Kong (2000), Available at: http://www.e-c.edu.hk/eng/reform/annex/Edu-reform-eng.pdf (accessed 10 February 2014).

11. Education Commission. Review of the Academic Structure of Senior Secondary Education (2003), Available at: http://www.e-c.edu.hk/eng/reform/rasih/RASIH-report-eng.pdf (accessed 10 February 2014).

12. Edward Vickers and Flora Kan. The Reeducation of Hong Kong: Identity, Politics, and Education in Postcolonial Hong Kong. American Asian Review. Vol. XXI, No. 4. 2003. Available at: http://civic-exchange.org/en/live/upload/files/200403_ReeducationPostcolonial.pdf (accessed 10 February 2014).

13. Finlex Data Bank. The Government Decree on the General National Objectives of General Upper Secondary Education and the Distribution of Lesson Hours (955/2002), Available at: http:// www.finlex.fi/fi/laki/ajantasa/2002/20020955 (accessed 10 February 2014).

14. Finnish Matriculation Examination 2007. Statistics from the Matriculation Examination Board (2007), Available at: http://www.ylioppilastutkinto.fi/Tilastoja/Matriculation_07_web.pdf (accessed 10 February 2014).

15. Global Perspectives: a framework for global education in Australian schools, Available at: http://www.globaleducation.edu.au/verve/_resources/GPS_web.pdf (accessed 10 February 2014).

16. Hong Kong Examinations and Assessment Authority. English Language. Assessment Framework for 2012 HKDSE. (2012a), Available at: http://www.hkeaa.edu.hk/DocLibrary/HKDSE/ Subject_Information/eng_lang/2012hkdse-e-elang.pdf (accessed 10 February 2014).

17. Hong Kong Examinations and Assessment Authority. English Language. Draft Level Descriptors. Subject Descriptors. Hong Kong Diploma of Secondary Education Examination. (2013a), Available at: http://www.hkeaa.edu.hk/DocLibrary/HKDSE/Subject_Information/eng_lang/eng-langlevel-descriptors.pdf (accessed 10 February 2014).

18. Hong Kong Examinations and Assessment Authority. English Language. Paper 1. (Sample Paper). Question-Answer Book. Hong Kong Diploma of Secondary Education Examination. (2013b), Available at: http://www.hkeaa.edu.hk/DocLibrary/HKDSE/Subject_Information/eng_lang/eng-langsample-papers-1234.pdf (accessed 10 February 2014). 
19. Hong Kong Examinations and Assessment Authority. Statistics Overview. 2012. Hong Kong Diploma of Secondary Education Examination. (2012b), Available at: http://www.hkeaa.edu.hk/DocLibrary/ HKDSE/Exam_Report/Examination_Statistics/dseexamstat12_1.pdf (accessed 10 February 2014).

20. Melbourne Declaration on Educational Goals for Young Australians, Available at: http://www. mceecdya.edu.au/verve/_resources/national_declaration_on_the_educational_goals_for_young australians.pdf (accessed 10 February 2014).

21. National Assessment Program - Civics and Citizenship. Assessment Framework. Available at: http://www.nap.edu.au/verve/_resources/NAP_CC_assessment_framework.pdf (accessed 10 February 2014).

22. National Assessment Program. Civics and Citizenship. Years 6 and 10. Report 2010. Available at: http://www.nap.edu.au/verve/_resources/NAP-CC_Report_2010_251011.pdf(accessed 10 February 2014).

23. New Academic Structure Web Bulletin. The New Academic Structure for Senior Secondary Education and Higher Education. Senior Secondary Education and Higher Education. 2004, Available at: http://334.edb.hkedcity.net/doc/eng/main.pdf (accessed 10 February 2014).

24. OECD.Definition and Selection ofCompetencies(DeSeCo). The Organisation forEconomic Cooperation and Development, Available at: http://www.oecd.org/edu/highereducationandadultlearning/ definitionandselectionofcompetenciesdeseco.htm (accessed 10 February 2014).

25. OECD. PISA 2009 key findings, Available at: http://www.oecd.org/pisa/keyfindings/ pisa2009keyfindings.htm (accessed 10 February 2014).

26. OECD. PISA 2012 Results in Focus: What 15-year-olds know and what they can do with what they know: Key results from PISA 2012, Available at: http://www.oecd.org/pisa/keyfindings/ pisa-2012-results-overview.pdf (accessed 10 February 2014).

27. OECD. PISA 2012 Results, Available at: http://www.oecd.org/pisa/keyfindings/pisa-2012results.htm (accessed 10 February 2014).

28. OECD. Programme for International Student Assessment (PISA). Learning for Tomorrow's World - First Results from PISA 2003, Available at: http:// www.oecd.org/edu/school/programmeforinternationalstudentassessmentpisa/ learningfortomorrowsworldfirstresultsfrompisa2003.htm (accessed 10 February 2014).

29. OECD. Programme for International Student Assessment (PISA). Literacy Skills for the World of Tomorrow: Further Results from PISA 2000 - Publications 2000, Available at: http:/www. oecd.org/edu/school/programmeforinternationalstudentassessmentpisa/literacyskillsfortheworldofto morrowfurtherresultsfrompisa2000-publications2000.htm (accessed 10 February 2014).

30. OECD. Programme for International Student Assessment (PISA). PISA 2006 results, Available at: http://www.oecd.org/edu/school/programmeforinternationalstudentassessmentpisa/ pisa2006results.htm (accessed 10 February 2014).

31. OECD. Reading for Change Performance and Engagement across Countries Results from Pisa 2000, Available at: http://www.oecd.org/edu/school/ programmeforinternationalstudentassessmentpisa/33690904.pdf (accessed 10 February 2014).

32. Russian Newspaper. Rossiyskaia Gazeta. Federal'nyy gosudarstvennyi obrazovatel'nyy standart obshchego obrazovaniia [The National Federal Secondary Standard], (2011), Available at: http://www.rg.ru/2011/02/17/shkola-standart-site-dok.html (accessed 10 February 2014). 
33. Savinov E.S. Approximate Basic Educational Program. Basic School. Moscow, Prosveshchenie, 2011, $342 \mathrm{p}$.

34. Singapore Examinations and Assessment Board. General Paper (2013), Available at: http:// www.seab.gov.sg/aLevel/2013Syllabus/8806_2013.pdf (accessed 10 February 2014).

35. Singapore Examinations and Assessment Board. General Paper, Available at: http://www. seab.gov.sg/aLevel/2013Syllabus/8806_2013.pdf (accessed 10 February 2014).

36. Singapore Examinations and Assessment Board. Knowledge and Inquiry Higher 2 (2013), Available at: http://www.seab.gov.sg/aLevel/2013Syllabus/9759_2013.pdf (accessed 10 February 2014).

37. The Adelaide Declaration on National Goals for Schooling in the Twenty-First Century, Available at: http://www.mceecdya.edu.au/mceecdya/adelaide_declaration_1999_text,28298.html (accessed 10 February 2014).

38. The Concept of Modernization of Russian Education for the Period up to 2010, Available at: http://edu.of.ru/isiorao/default.asp?ob_no=30288 (accessed 10 February 2014).

39. The Curriculum Development Council. The Student Programme to Achieve the Vision of the New Academic Structure Whole-person Development and Life-long Learning. Booklet 1. Senior Secondary Curriculum Guide. The Future Is Now: From Vision to Realisation (Secondary 4-6). Prepared by the Curriculum Development Council. Available at: http://cd1.edb.hkedcity.net/cd/cns/ sscg_web/pdf/eng/Booklet\%201\%20eng.pdf (accessed 10 February 2014).

40. The Federal Institute for Education Evaluation. Specification of Assessment Materials for State Final Attestation Social Science 2013, Available at: http://www.fipi.ru/view/sections/227/ docs/628.html (accessed 10 February 2014).

41. The Federal Institute for Education Evaluation. Specification of Assessment Materials for the Unified State Exam in Social Science 2013, Available at: http://www.fipi.ru/view/sections/226/ docs/627.html (accessed 10 February 2014).

42. Federal Law of Russia "On Education" (1992), Available at: http://xn--80abucjiibhv9a.xn-plai/\%D0\%B4\%D0\%BE\%D0\%BA\%D1\%83\%D0\%BC\%D0\%B5\%D0\%BD\%D1\%82\%D1\%8B/884 (accessed 10 February 2014).

43. Federal Law of Russia "on Education" (2012), Available at: http://xn--80abucjiibhv9a.xn--p 1ai/\%D0\%B4\%D0\%BE\%D0\%BA\%D1\%83\%D0\%BC\%D0\%B5\%D0\%BD\%D1\%82\%D1\%8B/2974 (accessed 10 February 2014).

44. Finnish Matriculation Examination. [Äidinkielen Kokeen Määräykset] (2012), Available at: http://www.ylioppilastutkinto.fi/Uudet_maaraykset/Aidinkielen_kokeen_maaraykset.pdf (accessed 10 February 2014).

45. Finnish National Board of Education (FNBE). National Core Curriculum for Basic Education 2004, Available at: http://www.oph.fi/download/47675_POPS_net_new_2.pdf (accessed 10 February 2014).

46. Finnish National Board of Education (FNBE). National Core Curriculum for Upper Secondary Schools 2003, Available at: http://www.oph.fi/download/47678_core_curricula_upper_secondary_ education.pdf (accessed 10 February 2014).

47. Hobart Declaration on Schooling (1989), Available at: http://www.mceecdya.edu.au/mceecdya/ hobart_declaration,11577.html (accessed 10 February 2014). 
48. Ministry of Education and Science of the Russian Federation. Governmental Draft State Program of the Russian Federation "Development of Education" for 2013-2020, Available at: http://xn-80abucjiibhv9a.xn--plai/\%D0\%B4\%D0\%BE\%D0\%BA\%D1\%83\%D0\%BC\%D0\%B5\%D0\%BD\%D1 \%82\%D1\%8B/2474/\%D1\%84\%D0\%B0\%D0\%B9\%D0\%BB/901/\%D0\%93\%D0\%BE\%D1\%81\%D0\% BF\%D1\%80\%D0\%BE\%D0\%B3\%D1\%80\%D0\%B0\%D0\%BC\%D0\%BC\%D0\%B0_\%D0\%A0\%D0\% B0\%D0\%B7\%D0\%B2\%D0\%B8\%D1\%82\%D0\%B8\%D0\%B5_\%D0\%BE\%D0\%B1\%D1\%80\%D0\%B 0\%D0\%B7\%D0\%BE\%D0\%B2\%D0\%B0\%D0\%BD\%D0\%B8\%D1\%8F_(\%D0\%9F\%D1\%80\%D0\%B E\%D0\%B5\%D0\%BA\%D1\%82).pdf (accessed 10 February 2014).

49. National Federal Basic Education Standard, Available at: http://xn--80abucjiibhv9a.xn--p 1ai/\%D0\%B4\%D0\%BE\%D0\%BA\%D1\%83\%D0\%BC\%D0\%B5\%D0\%BD\%D1\%82\%D1\%8B/938 (accessed 10 February 2014).

50. National Federal Standard for Secondary (Complete) Education, Available at: http://xn-80abucjiibhv9a.xn--plai/\%D0\%B4\%D0\%BE\%D0\%BA\%D1\%83\%D0\%BC\%D0\%B5\%D0\%BD\%D1 $\% 82 \% \mathrm{D} 1 \% 8 \mathrm{~B} / 2365 / \% \mathrm{D} 1 \% 84 \% \mathrm{D} 0 \% \mathrm{~B} 0 \% \mathrm{D} 0 \% \mathrm{~B} 9 \% \mathrm{D} 0 \% \mathrm{BB} / 736 / 12.05 .17-\% \mathrm{D} 0 \% 9 \mathrm{~F} \% \mathrm{D} 1 \% 80 \% \mathrm{D} 0 \%$ B8\%D0\%BA\%D0\%B0\%D0\%B7_413.pdf (accessed 10 February 2014).

51. Report of the Ministry of Education and Culture of Finland in 2012. Basic Education for the Future: National Objectives and Distribution of Hours [Tulevaisuuden perusopetus - valtakunnalliset tavoitteet ja tuntijako.Opetus- ja kulttuuriministeriön työryhmämuistioita ja selvityksiä] (2012), Available at: http://www.minedu.fi/export/sites/default/OPM/Julkaisut/2012/liitteet/tr06.pdf?lang=en (accessed 10 February 2014).

52. Russian Education Portal. State Education Standards (2004), Available at: http://www.school. edu.ru/dok_edu.asp?pg=2 (accessed 10 February 2014).

53. Work Sample Portfolio. History. Year 10. Satisfactory. Available at: http://www.acara.edu.au/ curriculum/worksamples/Year_10_History_Portfolio_Satisfactory.pdf (accessed 10 February 2014). 


\title{
Развитие критического мышления \\ у учащихся среднеобразовательных школ \\ как стратегический приоритет \\ современного образования: \\ цели, задачи, результаты
}

\author{
А.В. Самойлов \\ Московская высшая школа сочиальных и экономических наук \\ Россия, 119571, Москва, пр. Вернадского, 82, корп. 2
}

\begin{abstract}
Федеральные государственные стандарты образования определяют навыки критического мылиления как однуиз основных черт «портрета выпускника школы». В этом отночении навыки критического мышления, эффективность которых на каждом уровне может быть оценена с помощью специальных критериев, должны быть определены в государственных стандартах и программах. Данная статья представляет анализ зарубежного опыта (Сингапур, Финляндия, Гонконг и Австралия) развития критического мышления как возможный способ реализации идеологии критического мышления в российском школьном образовании. Автор предпринимает попытку определить ряд требований к обозначению основных критериев развития навыков критического мышления и предлагает некоторые методы оценки критического мышления, которые могли бы быть использованы авторами федеральных государственных стандартов.

Ключевые слова: критическое мышление, способы оченки, государственные стандарты и программы, критерии развития навыков критического мышления.
\end{abstract}

Научная специальность: 19.00.00 - психологические науки. 